


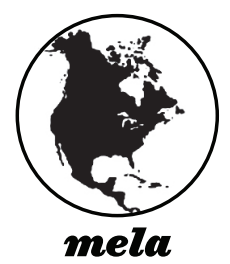

\section{multi-ethnic literatures of the americas}

AMRITJIT SINGH, CARLA L. PETERSON, C. LOK CHUA, SERIES EDITORS

The MELA series aims to expand and deepen our sense of American literatures as multicultural and multi-lingual and works to establish a broader understanding of "America" as a complex site for the creation of national, transnational, and global narratives. Volumes in the series focus on the recovery, consolidation, and reevaluation of literary expression in the United States, Canada, and the Caribbean as shaped by the experience of race, ethnicity, national origin, region, class, gender, and language.

M. E. Ravage

AN AMERICAN IN THE

MAKING: THE LIFE STORY OF

AN IMMIGRANT

EDITED BY Steven G. Kellman

Lin Yutang

CHINATOWN FAMILY

EDITED вY C. Lok Chua

Pauline E. Hopkins

DAUGHTER OF THE

REVOLUTION:

THE MAJOR NONFICTION

WORKS OF PAULINE E.

HOPKINS

EDITED BY Ira Dworkin

EMPIRE AND THE LITERATURE

OF SENSATION:

AN ANTHOLOGY OF

NINETEENTH-CENTURY

POPULAR FICTION

EDITED BY Jesse Alemán AND Shelley Streeby

Garibaldi M. Lapolla

THE GRAND GENNARO

EDITED BY Steven J. Belluscio
Kathleen Tamagawa

HOLY PRAYERS IN A HORSE'S

EAR: A JAPANESE AMERICAN

MEMOIR

EDITED BY Greg Robinson AND

Elena Tajima Creef

Claude McKay

A LONG WAY FROM HOME EDITED BY Gene Andrew Jarrett

SHADOWED DREAMS: WOMEN'S

POETRY OF THE HARLEM

RENAISSANCE

2ND EDITION, REVISED

AND EXPANDED

edITED by Maureen Honey

VISIONS AND DIVISIONS:

AMERICAN IMMIGRATION

LITERATURE, 1870-1930

edited by Tim Prchal And Tony Trigilio

ZORA NEALE HURSTON:

COLLECTED PLAYS

edITED BY Jean Lee Cole AND Charles Mitchell 
THE GRAND Gennaro 


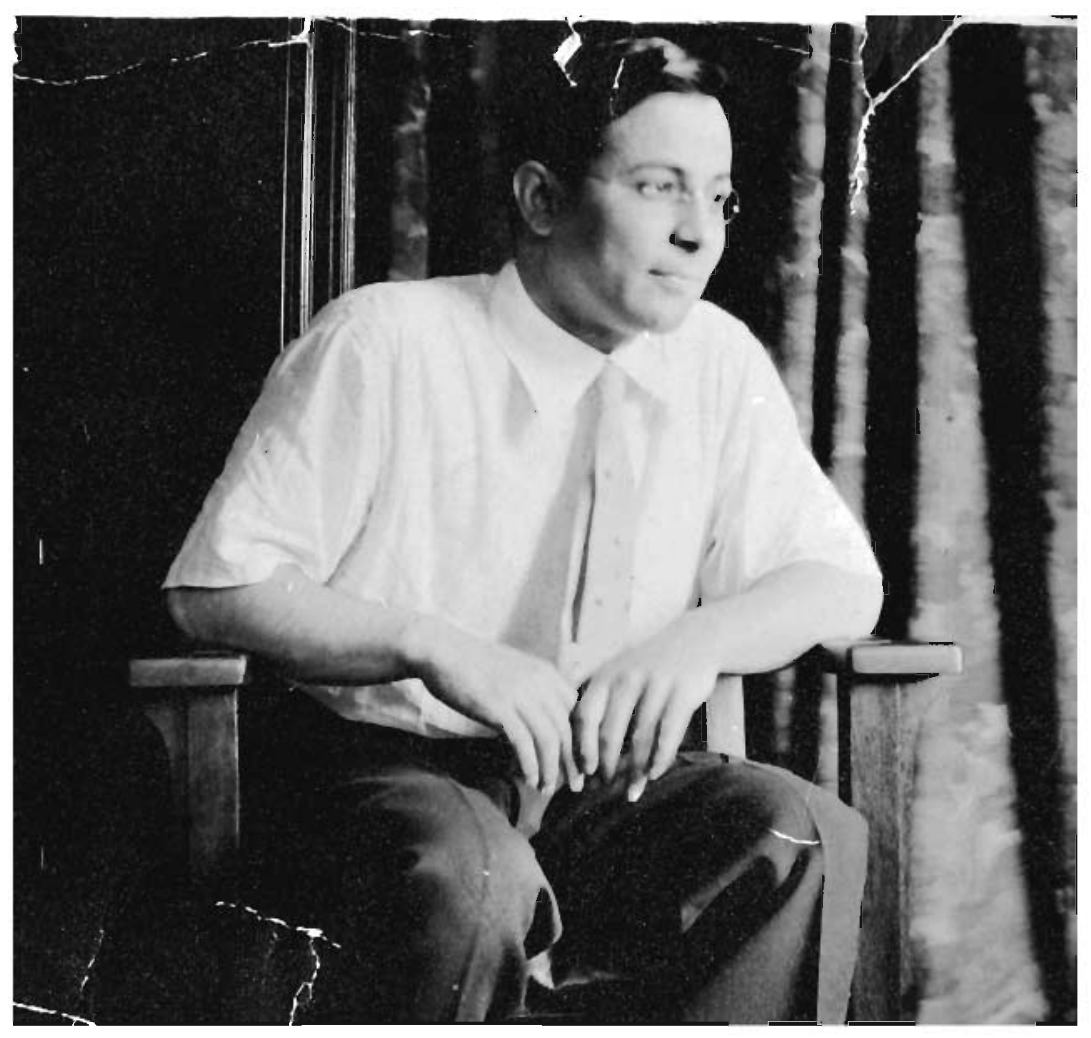




\section{THE GRAND Gennaro}

\section{Garibaldi M. Lapolla}

EDITED AND WITH AN INTRODUCTION BY Steven J. Belluscio 
Lapolla, Garibaldi M. (Garibaldi Marto), 1888-1954.

The grand Gennaro / Garibaldi M. Lapolla ; edited and with an introduction by Steven J. Belluscio.

p. cm. - (Multi-ethnic literatures of the Americas (MELA))

Includes bibliographical references.

ISBN 978-0-8135-4568-4 (hardcover : alk. paper) - ISBN 978-0-8135-4569-1 (pbk. : alk. paper)

1. Italian Americans-Fiction. 2. Immigrants-New York (State)-New York-Fiction. 3. Italian Americans-Social life and customs-Fiction. 4. New York (N.Y.)-History-1898-1951-Fiction.

I. Belluscio, Steven J. II. Title.

PS3523.A659G73 2009

$813 \cdot 52-\mathrm{dc} 22$

2008048063

A British Cataloging-in-Publication record for this book is available from the British Library.

This publication is supported in part by the Institute of Italian and Italian American Heritage Studies.

The Grand Gennaro was first published by Vanguard Press in 1935. All rights to the novel remain with Paul M. Lapolla.

Introduction and scholarly apparatus copyright $(\bigodot 2009$ by Steven J. Belluscio

All rights reserved

No part of this book may be reproduced or utilized in any form or by any means, electronic or mechanical, or by any information storage and retrieval system, without written permission from the publisher. Please contact Rutgers University Press, 100 Joyce Kilmer Avenue, Piscataway, NJ 08854-8099. The only exception to this prohibition is "fair use" as defined by U.S. copyright law.

Text design by Adam B. Bohannon

Visit our Web site: http://rutgerspress.rutgers.edu

Manufactured in the United States of America

Frontispiece: Portrait of Garibaldi M. Lapolla courtesy of The Historical Society of Pennsylvania (HSP), Garibaldi M. Lapolla Collection. 